\title{
Study on Advantages and Disadvantages of Cruise Charter Sailing Sales Mode in China
}

\author{
Xiaonan Li \\ No.8, Yashen Raod, Jinnan District, Tianjin City, China \\ lily2019151412@163.com
}

Keywords: Cruise; Charter sailing; Sales mode; Advantages and disadvantages

\begin{abstract}
With the explosive growth of China's cruise market, the amount of cruise charter sailing is also rapidly increasing. In 2015, the MERS epidemic in Korea and several typhoons have caused great damage to China's cruise market. As China's feature, cruise charter sailing sales mode is also questioned and denounced in the industry. This paper starts from the generation of cruise charter sailing sales mode, analyzes the advantages and disadvantages of cruise charter sailing sales mode in-depth and proposes corresponding countermeasures.
\end{abstract}

\section{Introduction}

In 2016, there were altogether 18 cruises at home ports in China (mainland). In addition, the Dream Cruise of Hong Kong's top-notch cruise brand "Seaway Maritime" is expected to be launched in November 2016. According to the cruise company's transport capacity in 2015, the total capacity of cruise at home ports in China in 2016 surpasses 50,000 standard cabins. The ever increasing supply further increase the sales pressure of agents. It remains to be discussed as whether charter sailing sales mode should take the initiative to withdraw from the rapidly developing cruise market in China or continue to progress and lead cruise sales mode.

\section{Generation of Cruise "Charter Sailing” Sales Mode}

What is Cruise "Charter Sailing" Sales Mode. Charter Sailing refers to the sales mode completely dominated by agents or customers by buying out all the available cabins of a certain voyage cruise in advanced. According to the different proportions of buyout, charter sailing can also be divided into different forms: half charter sailing and mega group. Half charter sailing refers to that agents or customers buy out half the cabins in advance, and mega group refers to that they buy out more than $50 \%$ but less than $100 \%$ cabins.

Originally, there was only one charter sailing mode in the global cruise market, i.e., the corporate charter sailing, which refers to that a certain company charter a certain cruise voyage and holds activities on the voyage for their customers or employees. The great advantage of this charter sailing is that all the cabins and services will not be openly sold on the market. The charter subject invites customers to go on the board free of charge of pay some fees for promotion or rewarding its staffs or customers instead of gaining profits from selling cruise tickets. Such charter sailing is a very beneficial supplement to the market.

Reasons for the Generation of "Charter Sailing" Sales Mode in China's Cruise. Different from corporate charter sailing, the cruise sales mode in China is "retailer charter sailing". On one hand, the charter subject is travel agencies. After signing a buyout agreement with the cruise company, travel agencies must pay the charter fees according to stipulations in the contract, and they can also make the sales price on their own. On the other hand, they directly gain profits from selling cruise tickets and providing on-shore sightseeing services.

Retailer charter sailing is the main distribution mode on China's cruise market and a sales mode with Chinese characteristics. And it is also one of the important driving forces that truly make China's cruise industry develop rapidly in recent five years and the main factor allowing cruise sales to be trapped into a dilemma. Charter mode can develop in China for special reasons: 
Firstly, Both China's National Tourism Bureau and local tourism bureaus require outbound agencies or companies to be travel agencies with the qualification to organize customers to go abroad so that even if a cruise company establishes its company in China, it cannot sell cruise tickets but cannot organize outbound sightseeing on its own. Therefore, overseas cruise companies usually package ship tickets to travel agencies for them to sell these tickets.

Secondly, The main destinations of cruises setting from China's home ports are Japan and Korea. In order to control the occurrence for Chinese visitors to illegal stay there, Chinese cruise visitors had better go there in groups. In order to attract Chinese cruise customers, such hope becomes more urgent after visa waiver for cruise customers.

\section{Analysis of the Advantages and Disadvantages of Cruise Charter Sailing Sales Mode}

"Advantages" of Cruise Charter Sailing Sales Mode. For Travel Agencies: Cruise charter sailing allows travel agencies to have the exclusive monopoly of a cruise voyage, especially in the summer season of the voyage, the voyage to other distributors selling tickets, products must obtain resources from the charter travel agency by cutting class mode. Cruise ships at the same time so that the package travel agencies enjoy pricing, can be fully independent pricing, so as to avoid other competitors price competition and channel conflict, but also conducive to the development of cruise tourism market share. The monopoly of resources, lower than other routes to sell bulk voyage and other distributors of price advantage and a full range of sales channels, to bring the boat travel is very considerable economic benefits. As one of the earliest cruise travel agency and cruise experts, U Tour from 2007 the first charter until the beginning of 2014, has been successfully created for eight consecutive years of operating cruise boat project in the cruise ship industry myth, package earned pours.

Cruise charter sailing is the embodiment of the economic strength of travel agencies, and to a certain extent, enhances the image of the enterprise. The cruise company's position, usually at the beginning of the year when they will plan to travel, the travel agency in advance buyout this huge "futures", is a huge challenge for enterprise funds, sales channels and operation ability, but once the operation is successful, corporate reputation, image and reputation will be greatly upgrade. As a luxury cruise can accommodate 3000 people for example, pack a voyage total funding in 10 million to 20 million yuan. Even in the sales process in 4 installments, and this process will have sales of cash flow, but also must have at least 5 million yuan in cash, is likely to pack a voyage. This is a huge challenge for the travel agency, which has always been a relatively tight cash flow.

For Cruise Companies: Cruise charter sailing will help to spread the pressure and risk of the sale of cruise ships. For the cruise company, first of all, the lack of adequate understanding of China tourism market and control, if you sell bulk voyage, may face enormous pressure sales and sales late due to the tail section of risk and return rate of the warehouse full of liquidated damage. Secondly, for the majority of Tourists Cruise China belongs to new things, compared to the travel agency, the cruise company is difficult to obtain the trust Chinese tourists, travel agencies as the third party for tourists and cruise companies to build trust and communication platform. Finally, the cruise company sold loose voyage the lack of strong sales channels and customers, and the travel agency is the biggest advantage of the full range of sales channels and the vast majority of tourist market.

Cruise ships to enable the company to save the cost of sales, while ensuring revenue. First of all, the cruise ship will be sold to the cost of the travel agency, the cruise company almost no sales of human and financial input, only a small amount of marketing funds and sales training for sales staff. Secondly, the largest gains in sales revenue is cruise tickets. Cruise ships to make the first half of the cruise company even a year and a half to lock this part of the revenue. At the same time the cruise package has full warehouse requirements ship sales model, namely the minimum number of boarding, so the cruise ship voyage (Onboard revenue) consumer income such as the casino, Spa, shopping has also been a number of consumption on the guarantee, so as to guarantee in advance of income and consumption on board. 
For Travelers: Cruise charter sailing sales mode provides convenience for travelers. In addition to applying for the visa, all the other procedures can be assuredly completed by the travel agencies. Boarding for foreign tourists can be divided into two steps: first of all, they need to complete online check-in and then print the cruise ticket/boarding pass and luggage tag, with which tourists can get the cruise seapass card at the cruise terminal and board. However, in China, the first step of board is completely completed by travel agencies, which provides great convenience for travelers.

"Disadvantages" of Cruise Charter Sailing Sales Mode. Behind the rapidly developing cruise market, there are also certain disadvantages to the cruise charter sailing mode. Especially, in 2015, influenced by the MERS and various typhoons, the cruise charter sailing sales mode became obviously week in resisting emergencies.

Cruise Charter Sailing Increases the Sales Pressure on Travel Agencies and Distorts Price, Bringing Serious Loss. Charter sailing can allow travel agents to control the resources and enjoy the right to pricing, but also make travel agencies face huge sales pressure. The travel agency according to the contract after full payment of the cost of package, at the same time charter agreement will be agreed full rate index, generally in $90 \%$, if the sales are not up to the index, travel agencies to pay the penalty according to the loss of cabin head, fine usually charter agreements specified price NPD (Net per Diem, standard passenger the amount of the price per bed per night). Such as the fine Royal Caribbean policy in 2014, when sales rate of less than $99 \%$ full cabin, the travel agency according to the head loss of cabin filled (according to the ticket prices). Thus, in the case of weak market, the travel agency in order to reduce the loss is likely to sell the tail cabin, it even spawned a number does not work directly with individual cruise company or agency, are weak, the business to throw a cabin by the market, wantonly fictitious, at a low price to attract tourists the price of the product, resulting in the cruise system is broken, the normal sales channels cannot be traded, will eventually lead to vicious spiral.

On the other hand, if the distribution capability is not strong enough or encounter unexpected events, such as bad weather, epidemic, etc., will result in a loss of travel agency distribution, resulting in a loss. For example, in 2015, South Korea's MERS epidemic, a major impact on travel agencies. Hangzhou, a chartered ship travel agency, a loss of more than 10 million yuan. As a result of the contract already in the beginning and the cruise company signed, the money in advance, even if did not receive the guest, cruise company will not refund.

Charter Sailing Brings Great Risk to Travel Agencies, Who Need to be Fully Responsible for Tourists. In addition to sales pressure, charter sailing mode also transfers huge operation to travel agencies. In today's charter sailing mode, the so-called "charter sailing" actually charters the cruise itself, but the travel agencies cannot control the service quality, route, and anchoring port, etc. So as to queuing for a long time, eating taste does not meet the conditions, problems are not solved in time and lack of individual projects, when these problems, the first reaction is to find the tourists and travel agencies, because tourists are tourists and travel agencies signed a contract, without any contractual relationship with cruise company. In particular, the force majeure factors leading to changes in the cruise or reduce the route, the tourists looking for nature as a tourist product operators and organizers of travel agencies. But on the one hand, the provisions of the international cruise industry related laws and regulations, because of force majeure, be exempt from the change of voyage cruise company, do not assume liability for breach of contract, although for tourists, interests indeed affected by the actual damage; on the other hand, the travel agency only undertakes the cruise sales work, have to bear effectively to solve this kind of accident responsibility, responsibility not so serious, therefore may face the loss of economy and credit.

In addition, in the charter sailing sales mode, charter sailing travel agencies have huge sales pressure, and they should also be responsible for leading the team, online check-in and shore excursion, etc. Therefore, with huge sales pressure, charter sailing travel agencies should focus on services. Sales staff training, lack of professional is not enough, cause the product and brand information is not very good at tourists, not only make the tourists experience affected, market development is also not ideal, and customers' feedback cannot be well received. 


\section{Countermeasures to Cruise Charter Sailing Sales Mode}

At present, due to the special cruise market in China, cruise charter sailing sales mode will take the dominating place for some time in the future, but for the orderly development of the cruise market, corresponding measures should be taken:

Domestic travel agencies should work together to jointly maintain the good and orderly cruise market. Faced with the cruise charter sailing sales mode with unequal rights and obligations, they should negotiate with cruise companies to gain more interests and preferential conditions, such as capital support for market promotion, professional training in cruise sales and full rate, etc. especially in terms of selling cruise tickets, only through the cooperation between cruise companies and charter sailing travel agencies, can there be win-win results on the market.

Although charter sailing sales mode is market behavior, it is also caused by unsound relevant laws and regulations and their disconnection with international standards. Therefore, the government should pace up formulating relevant laws and regulations, especially the formulation of cruise contract. Perfect laws can provide political and legal guarantee for travel agencies in China and visitors' interest.

The cruise mode is still dominant, but the proportion of cabins and sales to individual visitors should also be increased. In 2016, Royal Caribbean promoted the "ordinary group" reservation rule to small-and-medium-sized agents in China, suitable for travel agencies willing to be engaged in the sales of cruise products, but are not willing to bear too much risk and capital pressure. Through this reservation mode, the risks to travel agencies are reduced to the minimum, and in addition to subscription, the risk of air cabin will be borne by cruise companies and travel agencies can obtain certain commission. In addition to risks and profits, travel agencies can freely choose the type and quantity of guest room on the Espresso and divide few cabins for numerous voyages according to their own conditions, and unify the packaging sales to give full play to the long tail effect of marketing.

Choose voyages with novel themes, constantly explore new ports and new routes, and timely introduce theme travels and characteristic travels to increase the added value. For example, the "three-night-and-four-day" "Selena" cruise of Costa starting from Shanghai, and the "On-sea Dancing Contest" theme activity held by U-tour have brought visitors an unforgettable "dance" travel.

\section{Conclusion}

Although cruise charter sailing is a unique sales mode in China due to its special condition, it also leads to the prosperous development of China's cruise market. However, after the period of rapid development, there are also a series of disadvantages to cruise charter sailing, which are not natural to charter sailing, but are caused by policies, market demand and the lagging behind of concepts and cognitions of the rapid development of the cruise market. If they can be improved from these aspects, the cruise charter sailing sales mode may not necessary give full play to its huge advantages and contributions.

\section{References}

[1] http://www.traveldaily.cn/article/97674/1

[2] http://www.traveldaily.cn/article/97674/2

[3] http://www.traveldaily.cn/article/97714

[4] http://toutiao.com/i6229039240051687938/

[5] M.Huang: Journal of Qingdao Ocean Shipping Mariners College,Vol.37(2016)No.1,p.28-31.(In Chinese)

[6] X.N.Li: Journal of Tianjin Vocational Institute,Vol.17(2015)No.1,p.108-110.(In Chinese)

[7] http://www.5ihse.com/zixun/domestic/8679.html 
[8] http://www.bbtnews.com.cn/2015/1014/123261.shtml

[9] http://www.pinchain.com/article/51962

[10] http://epaper.bjnews.com.cn/html/2016-02/24/content_623686.htm?div=-1 